\title{
Coronary artery CTA. A case-based atlas
}

\section{Smuclovisky}

\author{
Springer New York Dordrecht Heidelberg London, 2011 \\ ISBN: 978-1-4419-0430-0 (hardcover) e-ISBN: 978-1-4419-0431-7 \\ ISBN: 978-1-4614-0949-6 (softcover) \\ DOI: 10.1007/978-4419-0431-7
}

Published online: 25 July 2013

(C) Springer-Verlag 2013

This book, in its 151 page case-based layout, is intended to present the reader with an overview of possible results in the field of coronary artery CT angiography (CCTA).

One will find six sections: coronary anatomy; congenital coronary and other anomalies; coronary artery disease; percutaneous coronary intervention; postsurgical revascularization; and extracoronary abnormalities.

Sections open with an introduction, followed by interesting case presentations (history; findings; diagnosis; discussion; pearls of wisdom and pitfalls) and close with a list of suggested readings (noteworthy are citations of papers published in "La Radiologia Medica").

Each case shows how a CCTA examination has to be reviewed and studied at the workstation by the use of source images, multiplanar reformat, curved multiplanar, maximum intensity projection, 3D volume rendered, visual analysis and virtual endoscopy images (sometimes followed by the related coronary angiography), in order to reach the correct diagnosis or suggest to the angiographist the need for an invasive procedure.

Images are of the highest quality, easily understandable, but, in a few cases missing proper arrow size.

This is an atlas which will be much appreciated by radiologists, cardiologists and cardiac surgeons as well as by trainees starting work and study in this field.
Questo volume, impostato nelle sue 151 pagine come presentazione di casi, ha lo scopo di offrire al lettore una disanima di quanto ottenibile nel campo dell'angio-TC delle arterie coronarie (CCTA).

Vi si troveranno sei sezioni: anatomia coronarica; anomalie congenite delle coronarie e non solo; malattie delle arterie coronarie; interventi percutanei; rivascolarizzazione post-chirurgica; anomalie extracoronariche.

Ogni sezione si apre con una introduzione seguita da una presentazione (storia clinica; reperti; diagnosi; discussione; spunti di saggezza e insidie) di casi clinici di interesse e si chiude con un elenco di letture suggerite (notevoli le citazioni di lavori pubblicati su "La Radiologia Medica").

Ciascun caso dimostra come ogni esame di CCTA debba essere rivisto e studiato alla consolle impiegando le immagini di origine, quelle di riformattazione multiplanare e cur$v a$, di proiezione di massima intensità, di volume $3 D$, nonché di analisi visiva e di endoscopia virtuale (cui fa seguito, talvolta, la relativa angiografia coronarica), in modo tale da porre una diagnosi corretta o suggerire all'angiografista la necessità di una procedura invasiva.

Le immagini sono di notevole qualità e di facile comprensione, in alcuni casi, tuttavia, prive di frecce indicative.

Questo atlante sarà molto apprezzato da radiologi, cardiologi e cardio-chirurghi, nonché dagli specializzandi che iniziano a lavorare e studiare questa materia.

Giampiero Beluffi

Via G. Franchi Maggi 5,

27100 Pavia, Italy

e-mail: gevbeluffi@gmail.com 